\title{
DIVERSI TERHADAP ANAK PELAKU TINDAK PIDANA DALAM SISTEM PERADILAN PIDANA ANAK
}

\author{
Novita Rindi Pratama \\ Anggota Polres Majalengka \\ e-mail: novitarindi@yahoo.com
}

\begin{abstract}
Abstrak-Anak sebagai bagian dari generasi muda merupakan aset dan penerus cita-cita perjuangan bangsa memiliki peran strategis dan mempunyai ciri serta sifat khusus yang menjamin kelangsungan eksistensi bangsa dan negara pada masa depan. Oleh karena itu, diperlukan pembinaan secara terus menerus demi kelangsungan hidup, pertumbuhan dan perkembangan fisik, mental dan sosial serta perlindungan dari segala kemungkinan yang membahayakan masa depan anak. Kejahatan anak yang setiap tahun selalu meningkat dan berkembang sangat meresahkan semua pihak, khususnya masyarakat. Salah satu upaya pencegahan dan penanggulangannya adalah melalui sistem peradilan anak dengan tujuan tidak hanya untuk menjatuhkan sanksi pidana bagi anak yang telah melakukan tindak pidana tetapi lebih difokuskan pada dasar pemikiran bahwa penjatuhan sanksi tersebut sebagai sarana perbaikan kondisi, pemeliharaan dan perlindungan anak dengan mengutamakan pendekatan keadilan restoratif melalui diversi.
\end{abstract}

\section{Kata Kunci: Anak, Sistem Peradilan Pidana Anak, Diversi, Tujuan Hukum.}

Abstract-Children as part of the young generation is an asset and the successor to the ideas of national struggle has a strategic role and has the special characteristics and special personalities that ensure the continuity of the nation and the state existence in the future. Therefore, continuous training is required for survival, growth and development of the physical, mental and social as well as protection from any possibility of endangering the child's future. Children crime that keeps increasing year over year, continues to grow and develop, and it worries people and gives them terrible trouble, especially the society. One of the prevention and mitigation is to take the crime through the juvenile justice system, with the aim that is not only to impose criminal sanctions for children who have committed a crime, but is more focused on the idea that the imposition of sanctions as a means of improving conditions, maintenance and protection of children with emphasizing on restorative justice approach through diversion.

Keywords: Children, Juvenile Justice System, Diversion, Legal Purpose.

\section{A. PENDAHULUAN}

Anak sebagai bagian dari generasi muda merupakan aset dan penerus cita-cita perjuangan bangsa memiliki peran strategis dan mempunyai ciri serta sifat khusus yang menjamin kelangsungan eksistensi bangsa dan negara pada masa depan. Oleh karena itu, diperlukan pembinaan secara terus menerus demi kelangsungan hidup, pertumbuhan dan perkembangan fisik, mental dan sosial serta perlindungan dari segala 
Novita Rindi Pratama, Diversi Terhadap Anak Pelaku Tindak Pidana Dalam Sistem Peradilan...

kemungkinan yang membahayakan atau merusak masa depan anak.

(Ediwarman, 2006:8).

Kehadiran globalisasi dalam kemajuan ilmu pengetahuan dan teknologi, pembangunan, komunikasi dan informasi serta gaya hidup saat ini membawa pengaruh besar terhadap segala aspek kehidupan tanpa mengenal batas usia sehingga membuat trend kejahatan turut mengalami modernisasi. Fenomena yang muncul saat ini adalah bahwa kejahatan anak setiap tahun selalu meningkat dan berkembang dengan cepat baik dari kualitas maupun modus operandi yang dilakukan sangat meresahkan semua pihak, khususnya masyarakat.

\section{Diagram Anak Berhadapan dengan} Hukum tahun 2011-2016.

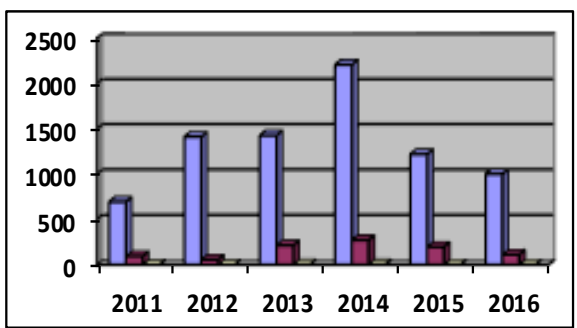

Salah satu upaya pencegahan dan penanggulangan kenakalan anak (politik kriminal anak) saat ini melalui penyelenggaraan sistem peradilan anak (juvenile justice) (Marlina, 2010:1).

Tujuan penyelenggaraan sistem peradilan anak tidak semata-mata bertujuan untuk menjatuhkan sanksi pidana bagi anak yang telah melakukan tindak pidana, tetapi lebih difokuskan pada dasar pemikiran, bahwa penjatuhan sanksi tersebut sebagai sarana mendukung mewujudkan kesejahteraan anak pelaku tindak pidana. (Marlina, 2010:1).

Untuk melakukan perlindungan terhadap anak dari pengaruh proses formal sistem peradilan pidana, maka timbul pemikiran manusia atau para ahli hukum dan kemanusiaan untuk membuat aturan formal tindakan mengeluarkan (remove) seorang anak yang melakukan pelanggaran hukum. United Nations Standard Minimum Rules for the Administration of Juvenile Justice (The Beijing Rules) telah memberikan pedoman sebagai upaya menghindari efek negatif tersebut. Yaitu dengan memberikan kewenangan kepada aparat penegak hukum mengambil tindakan-tindakan kebijakan dalam menangani atau menyeleseikan masalah pelanggar 
anak dengan tidak mengambil jalan formal, antara lain menghentikan atau tidak meneruskan atau melepaskan dari proses pengadilan atau mengembalikan/menyerahkan kepada masyarakat dan bentuk-bentuk kegiatan pelayanan sosial lainnya. Tindakan inilah yang disebut diversi (Setya Wahyudi, 2011:4) dan tentunya prinsip perlindungan hukum terhadap anak ini harus sesuai dengan Konvensi Hak Anak-Anak (Convention on the Rights of the Child) sebagaimana telah diratifikasi oleh Pemerintah Republik Indonesia dengan Keputusan Presiden Nomor 36 Tahun 1990 tentang Pengesahan Convention on the Rights of the Child (Kementrian Pemberdayaan Perempuan dan Perlindungan Anak Republik Indonesia, 2016:63).

Berdasarkan pengamatan ICJR, Pemerintah memiliki kewajiban dalam mengeluarkan setidaknya 6 (enam) Peraturan Pemerintah dan 2 (dua) Peraturan Presiden yang kewajiban tersebut telah diamanatkan dalam berbagai pasal di UndangUndang Nomor 11 Tahun 2012 tentang Sistem Peradilan Pidana Anak (www.icjr.or.id, diakses 11 Juli 2016). Namun permasalahan yang muncul adalah belum terwujudnya kewajiban Pemerintah dalam mengeluarkan 6 (enam) Peraturan Pemerintah dan 2 (dua) Peraturan Presiden sampai dengan saat ini sebagaimana yang telah diamanatkan ke dalam Pasal 107 Undang-Undang Nomor 11 Tahun 2012 tentang Sistem Peradilan Pidana Anak mengenai penetapan peraturan pelaksanaan Undang-Undang yang harus ditetapkan paling lambat 1 (satu) tahun sejak Undang-Undang Nomor 11 Tahun 2012 tentang Sistem Peradilan Pidana Anak diberlakukan, yakni tanggal 30 Juli 2016 menimbulkan persoalan baru mengenai bagaimana implementasi diversi yang selama ini dilakukan terhadap anak sebagai pelaku tindak pidana dan bagaimana evaluasi dari hasil pelaksanaan diversi yang telah dilakukan tersebut? Sehingga tujuan dari penelitian ini adalah untuk mengetahui implementasi diversi yang telah dilakukan dan evaluasi pelaksanaan diversi. 
B. HASIL DAN PEMBAHASAN

1. Implementasi

Diversi

Terhadap Anak Sebagai

Pelaku Tindak Pidana Dalam

Sistem Peradilan Pidana

Anak Dihubungkan Dengan

Tujuan Hukum

Ide diversi yang dicanangkan

dalam United Nations Standard minimum Rules for the Admnistration of Juvenile Justice (The Beijing Rules), yang tercantum dalam Rule 11.1, 11.2, dan 17.4 merupakan standar Internasional yang dikehendaki untuk diimplementasikan di negara-negara anggota PBB termasuk sistem peradilan pidana di Indonesia (Romli Atmasasmita, 2007:201). Praktek diversi mulai diberlakukan di Indonesia sejak 30 Juli 2014, yakni 2 (dua) tahun kemudian setelah diberlakukannya Undang-Undang Nomor 11 Tahun 2012 tentang Sistem Peradilan Pidana di Jakarta pada tanggal 30 Juli 2012 berdasarkan pertimbangan bahwa Undang-Undang Nomor 3 Tahun 1997 tentang Pengadilan Anak sudah tidak sesuai lagi dengan perkembangan dan kebutuhan hukum masyarakat karena belum secara komprehensif

memberikan perlindungan kepada anak yang berhadapan dengan hukum sehingga perlu diganti dengan Undang-Undang baru, maka dibentuklah UndangUndang Nomor 11 Tahun 2012 tentang Sistem Peradilan Pidana Anak.

Dalam Sistem Peradilan Pidana Anak, proses penanganan perkara terhadap anak sebagai pelaku tindak pidana mewajibkan penyidik, penuntut umum, dan hakim melaksanakan diversi dan mengutamakan keadilan restoratif. Diversi adalah pengalihan penyeleseian perkara anak dari proses peradilan pidana ke proses di luar peradilan pidana, sehingga dalam prosesnya, tidak hanya melibatkan para aparat penengak hukum saja melainkan turut serta melibatkan Pembimbing Kemasyarakatan, Pekerja Sosial Profesional, dan orang tua/wali korban anak korban serta anak pelaku.

Anak berhadapan dengan hukum dalam Undang-Undang Nomor 11 Tahun 2012 tentang Sistem Peradilan Pidana Anak (selanjutnya disebut UUSPPA) menjelaskan 
Novita Rindi Pratama, Diversi Terhadap Anak Pelaku Tindak Pidana Dalam Sistem Peradilan...

bahwa anak yang berhadapan dengan hukum diantaranya adalah anak yang berkonflik dengan hukum, anak yang menjadi korban tindak pidana, dan anak yang menjadi saksi tindak pidana, sehingga munculnya UUSPPA membawa perubahan terhadap penyebutan anak yang berhadapan dengan hukum ini menjadi: anak pelaku, anak korban dan anak saksi, hal ini bertujuan untuk menghindarkan anak dari stigmatisasi dan telah dipakai sejak UUSPPA diberlakukan. Dalam penanganan perkaranya, register perkara anak pelaku, anak korban dan anak saksi juga dibuat secara khusus dan terpisah dari perkara orang dewasa oleh lembaga yang menangani perkara anak.

Pelaksanaan diversi ini didukung oleh berbagai landasan hukum yang pengimplementasiannya sangat erat dengan Undang-Undang Nomor 35 Tahun 2014 Tentang Perubahan Atas Undang-Undang Nomor 23 Tahun 2002 Tentang Perlindungan Anak dan Peraturan Pengganti Undang-Undang
(Selanjutnya Disebut Perpu) Nomor 1 Tahun 2016 Tentang Perubahan Kedua Atas Undang-Undang Nomor 23 Tahun 2002 Tentang Perlindungan Anak. Hal ini dikarenakan masalah anak-anak merupakan delik biasa yang menganut asas lex specialist derogat legi generalis dimana Undang-Undang yang khusus mengenyampingkan Undang-Undang yang umum .

Berdasarkan penelitian di wilayah hukum Kabupaten Majalengka, kasus masalah perempuan dan anak yang masuk ke dalam Unit PPA Polres Majalengka memiliki jumlah yang hampir sama di antara kejahatan umum lainnya walaupun masih berkonsentrasi kepada kejahatan tindak pidana kepada anak dengan jenis persetubuhan dan pencabulan karena memiliki perbandingan jumlah yang signifikan di antara kejahatan pidana anak lainnya. Hal ini dapat dilihat berdasarkan data kasus 6 (enam) tahun terakhir di Wilayah Hukum Polres Majalengka adalah sebagai berikut: 
Data Kasus Unit PPA Polres Majalengka Tahun 2011-2016

\begin{tabular}{|l|c|c|c|c|c|c|}
\hline \multirow{2}{*}{ Tindak Pidana } & \multicolumn{7}{c|}{ Tahun } \\
\cline { 2 - 8 } & $\mathbf{2 0 1 1}$ & $\mathbf{2 0 1 2}$ & $\mathbf{2 0 1 3}$ & $\mathbf{2 0 1 4}$ & $\mathbf{2 0 1 5}$ & $\mathbf{2 0 1 6}$ \\
\hline Persetubuhan anak & 19 & 11 & 14 & 9 & 12 & 20 \\
\hline Pencabulan anak & 2 & 8 & 2 & 4 & 6 & 6 \\
\hline Penganiayaan & - & 1 & & 3 & 2 & - \\
\hline Eksploitasi ekonomi & - & - & - & - & - & 1 \\
\hline Tindak pidana perdagangan orang & - & - & 3 & - & - & - \\
\hline Kekerasan dalam rumah tangga & - & - & 2 & 1 & - & 6 \\
\hline Penempatan TKI di luar negeri & - & - & - & - & - & 1 \\
\hline Pembuangan bayi & - & - & - & - & - & 1 \\
\hline Ancaman melalui UU ITE & - & - & - & - & - & 1 \\
\hline Perkosaan & - & - & - & - & - & 1 \\
\hline Penelantaran keluarga & - & - & 1 & - & - & - \\
\hline Penculikan & - & 1 & 1 & - & - & - \\
\hline Pencurian & - & - & - & - & - & - \\
\hline & $\mathbf{2 1}$ & $\mathbf{2 0}$ & $\mathbf{2 3}$ & $\mathbf{1 7}$ & $\mathbf{2 0}$ & $\mathbf{3 9}$ \\
\hline
\end{tabular}

Tabel di atas menunjukkan bahwa tindak pidana yang terjadi kepada anak lebih berkonsetrasi kepada tindak pidana persetubuhan anak di bawah umur dan pencabulan terhadap pelaku di bawah umur yang mana tindak pidana ini merupakan tindak pidana berat karena ancaman hukuman pidana dalam UndangUndang Nomor 35 Tahun 2014 Tentang Perubahan Atas UndangUndang Nomor 23 Tahun 2002 Tentang Perlindungan Anak ini mengandung ancaman hukuman pidana penjara 5 (lima) sampai dengan 15 (lima belas) tahun dan denda paling banyak Rp. 5.000.000.000,00 (lima miliar rupiah) sebagaiman tercantum dalam Pasal Pasal 76 D, Pasal 76 E, Pasal 81 dan Pasal 82. Kasus persetubuhan yang marak terjadi di Wilayah Hukum Polres Majalengka dengan ancaman hukuman pidana penjara 5 (lima) sampai 15 (lima belas) tahun membuat pelaksanaan diversi belum bisa diimplementasikan sepenuhnya karena syarat diversi sebagaimana yang dicantumkan dalam Pasal 7 Undang-Undang Nomor 11 Tahun 2012 Tentang Sistem Peradilan Pidana Anak adalah:

a. Diancam dengan pidana penjara dibawah 7 (tujuh) tahun, dan

b. Bukan merupakan pengulangan tindak pidana. 
Oleh karenanya implementasi diversi di Kepolisian khusunya Polres Majalengka belum bisa terlaksana sepenuhnya karena kasus yang menonjol adalah persetubuhan dan pencabulan. Namun ada beberapa kasus yang terjadi di Wilayah Hukum Polres Majalengka menggunakan penyeleseian diversi dengan Surat Penetapan Diversi oleh Pengadilan Negeri Majalengka karena merupakan kejahatan ringan dan ancaman hukuman pidana penjara di bawah 7 (tujuh) tahun sehingga bisa memenuhi syarat diversi sebagaimana yang dimaksud oleh Pasal 7 UndangUndang Nomor 11 Tahun 2012 Tentang Sistem Peradilan Pidana Anak. Kasus tersebut adalah:

a. Kasus pencurian dengan pelaku anak di bawah umur di Kecamatan Ligung Kabupaten Majalengka, dilaksanakan diversi di Kepolisian dengan penetapan diversi nomor surat penetapan nomor: 02/Pen.Div/2015/PN.Mj1 tanggal 15 Januari 2015 yang telah memutus perkara terhadap anak atas nama tersangka Yudi Yusuf Subagja bin Makmur Hidayat, umur 17 (tujuh belas) tahun, status pelajar, diputuskan perkaranya dengan diserahkan kembali kepada orang tua tersangka untuk di didik dan diawasi karena selaku orang tua telah menyanggupi untuk mendidik dan mengawasi anak kandungnya lebih ketat lagi serta selama proses di didik orang tuanya, anak tersebut berada di bawah pengawasan pihak Balai Pemasyarakatan Cirebon dan Dinas Sosial Kabupaten Majalengka

b. Kasus pencurian dengan pelaku anak di bawah umur di Kecamatan Ligung Kabupaten Majalengka, dilaksanakan diversi di Kepolisian dengan penetapan diversi nomor surat penetapan nomor: 03/Pen.Div/2015/PN.Mjl tanggal 24 Juni 2015 yang telah memutus perkara terhadap anak atas nama tersangka Amsori Alias Amsor bin Rasmin, umur 14 (empat belas) tahun, status bekerja sebagai buruh bangunan, diputuskan perkaranya dengan diserahkan kembali kepada orang tua tersangka untuk di didik dan diawasi karena selaku orang tua telah menyanggupi untuk mendidik dan mengawasi anak 
kandungnya lebih ketat lagi serta selama proses di didik orang tuanya, anak tersebut berada di bawah pengawasan pihak Balai Pemasyarakatan Cirebon dan Dinas Sosial Kabupaten Majalengka.

c. Kasus percobaan pencurian dengan pemberatan dengan pelaku anak di bawah umur di Kecamatan Ligung Kabupaten Majalengka, dilaksanakan diversi di Kepolisian dengan penetapan diversi nomor surat penetapan nomor: 04/Pen.Div/2015/PN.Mjl tanggal 1 Oktober 2015 yang telah memutus perkara terhadap anak atas nama tersangka Sukma Priatna Putra bin Yayat Supriyatna, umur 14 (empat belas) tahun, status belum bekerja diputuskan perkaranya dengan diserahkan kembali kepada orang tua tersangka untuk di didik dan diawasi karena selaku orang tua telah menyanggupi untuk mendidik dan mengawasi anak kandungnya lebih ketat lagi serta selama proses di didik orang tuanya, anak tersebut berada di bawah pengawasan pihak Balai Pemasyarakatan Cirebon dan
Dinas Sosial Kabupaten Majalengka.

d. Kasus pencabulan dengan kekerasan dengan pelaku anak di bawah umur di Kecamatan Cikijing Kabupaten Majalengka, dilaksanakan diversi di Pengadilan dengan penetapan diversi nomor surat penetapan nomor: 05/Pen.Div/2016/PN.Mj1 tanggal 16 Mei 2016 yang telah memutus perkara terhadap anak atas nama tersangka Teghar Giri Agung Sugiharto bin Ugih Sugiharto, umur 16 (enam belas) tahun, status pelajar, diputuskan perkaranya dengan menghentikan proses pemeriksan terdakwa Teghar Giri Agung Sugiharto bin Ugih Sugiharto dan memerintahkan penuntut umum untuk mengeluarkan terdakwa dari tahanan serta memerintahkan panitera atau pejabat yang ditunjuk untuk mengirimkan salinan penetapan ini kepada anak, orang tua/walinya, penasihat hukum, korban, orang tua/walinya, pembimbing kemasyarakatan, pekerja sosial dan penuntut umum. 
Novita Rindi Pratama, Diversi Terhadap Anak Pelaku Tindak Pidana Dalam Sistem Peradilan...

Anak berhadapan dengan perbuatan yang dinyatakan dilarang hukum sebagai anak pelaku sangat bagi anak, baik menurut peraturan erat dikaitkan dengan Juvenile perundang-undangan maupun Delinquency dimana Romli menurut peraturan hukum lain yang Atmasasmita menjabarkan bahwa hidup dan berlaku dalam masyarakat Juvenile Delinquency adalah setiap perbuatan atau tingkah laku seseorang anak di bawah umur 18 tahun dan belum kawin yang merupakan pelanggaran terhadap norma-norma hukum yang berlaku serta dapat membahayakan perkembangan pribadi si anak yang bersangkutan (Wagiati Soetodjo dan Melani, 2004:11). Seseorang dikatakan anak adalah dimana mereka seseorang yang belum memiliki usia 18 tahun dan termasuk masih dalam kandungan. Sedangkan perbuatan yang merupakan pelanggaran terhadap norma-norma hukum yang berlaku serta dapat membahayakan perkembangan pribadi si anak yang bersangkutan, dalam KUHP bahwa salah satu unsur tindak pidana adalah harus terdapatnya unsur perbuatan manusia, kesalahan, dan melawan suatu ketentuan hukum. Dalam Undang-Undang Nomor 3 Tahun 1997 tentang Pengadilan Anak bahwa perbuatan tersebut merupakan yang bersangkutan.

Dalam perkembangannya, anak berhadapan dengan hukum sebagai anak pelaku di Wilayah Hukum Polres Majalengka mengalami kenaikan walaupun masih dalam jumlah yang bisa di kontrol. Hal ini sulit untuk dicegah seiring meningkatnya kemajuan teknologi yang dikuasai oleh para remaja dan melemahnya fungsi kontrol sosial orang tua, masyarakat dan sekolah. Sehingga pada akhirnya, dalam menghadapi anak-anak yang telah melakukan tindak pidana, yang penting baginya bukanlah apakah anak-anak tersebut dapat dihukum atau tidak, melainkan tindakan yang bagaimanakah yang harus diambil untuk mendidik anak-anak seperti itu. Berdasarkan pertimbangan di atas, Unit PPA Polres Majalengka selalu berkoordinasi dengan BPMDPKB (Badan Pemberdayaan Masyarakat Desa Perempuan Keluarga Berencana) dan Dinas Sosial 
Novita Rindi Pratama, Diversi Terhadap Anak Pelaku Tindak Pidana Dalam Sistem Peradilan...

Kabupaten Majalengka dalam Proses pengambilan keputusan membangun kerja sama untuk diatur lebih lanjut dalam Pasal 21 melaksanakan sosialisasi dan Undang-Undang Nomor 11 Tahun membangkitkan kesadaran hukum 2012 tentang Sistem Peradilan Pidana pada setiap lapisan masyarakat Anak dan Peraturan Pemerintah terhadap masalah sosial anak yang Nomor 65 Tahun 2015 Tentang terjadi tanpa disadari. Hal ini di harap mampu mengurangi jumlah anak berhadapan dengan hukum karena masyarakat yang telah sadar hukum ini akan sebagai fungsi preventif yang hidup di dalam lingkungannya. Pencegahan dan penanggulangan tindak kriminal harus dilakukan secara integral baik oleh pemerintah, orang tua, dan masyarakat. Penggunaan sanksi penal hanyalah upaya terakhir dalam menanggulangi tindak kejahatan terutama terhadap anak sebagai pelaku tindak pidana.

Proses peradilan anak pada dasarnya mengacu pada hukum acara dari peradilan umum, namum sejak berlakunya Undang-Undang Nomor 11 Tahun 2012 Tentang Sistem Peradilan Pidana, hukum acara dari peradilan umum tidak lagi digunakan dan merubah arah penanganan perkara anak kepada pengambilan keputusan dan pelaksanaan diversi. Pedoman Pelaksanaan Diversi dan Penanganan Anak Yang Belum Berumur 12 Tahun. Proses pengambilan keputusan ini merupakan sarana penghindaran anak dari sistem peradilan pidana kepada pelaku anak yang berumur di bawah 12 (dua belas tahun) sehingga dimaksudkan anak pelaku dibawah 12 (dua belas tahun) yang melakukan tindak pidana kejahatan ringan maupun berat tidak dilanjutkan ke sidang anak, melainkan cukup diselenggarakannya proses pengambilan keputusan dengan mempertimbangkan hasil penelitian bapas dan penetapan pengambilan keputusan dari pengadilan, sedangkan proses pelaksanaan diversi dilakukan melalui musyawarah dengan melibatkan anak dan orang tua atau walinya, korban dan orang tua atau walinya, Pembimbing Kemasyarakatan, dan Pekerja Sosial Profesional dengan syarat bahwa hal 
Novita Rindi Pratama, Diversi Terhadap Anak Pelaku Tindak Pidana Dalam Sistem Peradilan...

tindak pidana yang dilakukan diancam dengan tindak pidana penjara dibawah 7 (tujuh) tahun dan bukan merupakan pengulangan tindak pidana.

Proses pemeriksaan terhadap anak pelaku oleh Penyidik Unit PPA Polres Majalengka dilaksanakan dengan suasana kekeluargaan dimana lebih mengedepankan Polwan dengan mempertimbangkan penyidik yang mempunyai minat, perhatian, dedikasi serta memahami masalah anak. Pemeriksaan anak pelaku dilaksanakan di Ruang Ramah Anak Sat Reskrim Polres Majalengka tanpa diskriminasi dan tanpa menggunakan uniform kepolisian. Proses pemeriksaan anak pelaku dilaksanakan dengan pendampingan orang tua/walinya serta memperbolehkan anak pelaku untuk didampingi penasihat hukumnya. Kesepakatan diversi dalam UndangUndang Nomor 11 Tahun 2012 tentang Sistem Peradilan Pidana dapat dilakukan oleh Penyidik atas rekomendasi Pembimbing Kemasyarakatan dapat berbentuk:

a. Pengembalian kerugian dalam hal ada korban; b. Rehabilitasi medis dan psikososial;

c. Penyerahan kembali kepada orang tua/wali;

d. Keikutsertaan dalam pendidikan atau pelatihan di lembaga pendidikan atau LPKS paling lama 3 (tiga) bulan;

e. Pelayanan masyarakat paling lama 3 (tiga) bulan.

Jika implementasi diversi dihubungkan dengan paham abolisionisme yang mengatakan ingin membentuk masyarakat yang bebas dengan cara menghapus penjarapenjara sebagai refleksi pemikiran yang punitif dan menghindarkan pelaku tindak pidana dari proses peradilan yang formal dan menggantikannya dengan sistem kelembagaan yang berorientasi pada masyarakat, maka terdapat beberapa hal tentang kesamaan visi maupun misi pendapat paham abolisionis dengan misi tujuan implementasi ide diversi dalam sistem peradilan pidana anak, yaitu:

a. Implementasi ide diversi merupakan pengalihan struktur sistem peradilan pidana pada umumnya. Paham abolisionis menghendaki perubahan struktur 
sistem peradilan pidana yang telah mapan saat ini.

b. Implmentasi ide diversi dilakukan untuk menghindari efek buruk proses peradilan pidana. Hal ini diakui pula oleh paham abolisionis bahwa sistem peradilan pidana membawa atau menimbulkan penderitaan.

c. Diversi sebagai salah satu upaya menghindarkan pelaku tindak pidana dari proses peradilan yang formal dan menggantikannya dengan sistem kelembagaan yang berorientasi pada masyarakat ini, merupakan salah satu usulan dari pandangan paham abolisionis.

d. Pandangan abolisionis ingin membentuk masyarakat yang bebas dengan cara menghapus penjara-penjara sebagai refleksi pemikiran yang punitif. Hal ini tentuakan sesuai jika diterapkan pada pelaku anak, karena pidana penjara bagi anak menimbulkan efek negatif yang nyata (stigma dan prisonisasi pelaku anak). Implementasi ide diversi merupakan upaya agar anak terhindar dari sanksi pidana penjara.
Selanjutnya jika implementasi diversi terhadap anak sebagai pelaku tindak pidana ini dihubungkan dengan tujuan hukum yang menurut Gustav Radbruch, tujuan hukum adalah keadilan, kepastian hukum dan kemanfaatan, dengan menggunakan asas prioritas maka implementasi diversi dengan tujuannya sebagaimana yang tercantum dalam Undang-Undang Nomor 11 Tahun 2012 tentang Sistem Peradilan Pidana anak dalam Pasal 6 disebutkan tujuan diversi adalah:

a) Mencapai perdamaian antara korban dan anak

b) Menyeleseikan perkara anak di luar proses peradilan

c) Menghindarkan anak dari perampasan kemerdekaan

d) Mendorong masyarakat untuk berpartisipasi dan

e) Menanamkan rasa tanggung jawab terhadap anak.

Dan proses diversi tidak akan berhasil tanpa adanya hasil kesepakatan diantara kedua belah pihak, maka tujuan hukum akan lebih mengedepankan keadilan, kemanfaatan dan kepastian hukum 
sehingga tujuan hukum akan lebih terasa dan adil di mata masyarakat.

\section{Evaluasi Diversi Terhadap} Anak Sebagai Pelaku Tindak Pidana Dalam Sistem Peradilan Pidana Anak Di Wilayah Hukum Kabupaten Majalengka

Evaluasi merupakan sebuah pengumpulan data untuk menentukan sejauh mana, dalam hal apa, dan bagian mana tujuan tercapai. Jika belum, bagaimana yang belum dan apa sebabnya. Definisi ini diperluaskan oleh dua ahli lain, yakni Cronbach dan Stufflebeam. Tambahan definisi tersebut adalah bahwa proses evaluasi bukan sekedar mengukur sejauh mana tujuan tercapai, digunakan untuk membuat keputusan (Suharsimi Arikunto, 2006:3)

Setelah melakukan penelitian terhadap implementasi diversi terhadap anak sebagai pelaku tindak pidana dalam sistem peradilan pidana anak di Wilayah Hukum Kabupaten Majalengka, peneliti menemukan hambatan-hambatan yang mempengaruhi implementasi diversi tidak berjalan dengan baik di Wilayah Hukum Kabupaten Majalengka. Adapun hambatan-hambatan itu adalah:

a. Kurangnya penyidik anak didalam struktur organisasi unit PPA Polres Majalengka

Unit PPA Polres Majalengka memiliki struktur organisasi yang terdiri 1 (satu) Satu Kanit dengan status penyidik anak, dan 6 (enam) anggota dengan status penyidik pembantu. Sehingga penyidik anak di dalam Unit PPA Satuan Reskrim Polres Majalengka masih belum memenuhi harapan UndangUndang Nomor 11 Tahun 2012 Tentang Sistem Peradilan Pidana Anak karena hanya terdapat 1 (satu) Penyidik Anak di dalam Unit PPA Polres Majalengka. Untuk mendapatkan sertifikasi penyidik, para penyidik umum harus mengikuti pelatihan yang berkonsentrasi terhadap masalah anak yang diselenggarakan oleh pusat yang dalam hal ini adalah Kepolisian Daerah. Namun belum adanya kesempatan pelatihan dari Pusat atau dalam hal ini adalah Polda, membuat para penyidik 
pembantu di daerah mengalami kesulitan dalam memiliki sertifikat penyidik anak karena menurut Peraturan Presiden Nomor 175 Tahun 2014 Tentang Pendidikan dan Pelatihan Terpadu bagi Penegak Hukum dan Pihak Terkait Mengenai Sistem Peradilan Pidana Anak Pasal 8 adalah bahwa dalam pendidikan dan pelatihan terpadu dilaksanakan paling singkat selama 120 (seratus dua puluh jam) dan 1 (satu) jam pelajaran dilaksanakan selama 45 (empat puluh lima) menit. Pendidikan dan pelatihan terpadu adalah proses penyelenggaraan belajar mengajar yang bersifat teknis bagi penegak hukum dan pihak terkait mengenai Sistem Peradilan Pidana Anak dalam satu kesatuan proses pembelajaran dengan tujuan untuk menyamakan persepsi dalam penanganan anak yang berhadapan dengan hukum dalam sistem peradilan pidana anak

b. Tidak adanya lembaga P2TP2A di Wilayah Hukum Kabupaten Majalengka

Salah satu pertimbangan pembentukan P2TP2A adalah karena perempuan dan anak-anak yang secara sosial budaya merupakan kelompok rentan yang mengalami kekerasan dan eksploitasi serta belum terlaksananya secara penuh perlindungan dan pemberdayaan terhadap perempuan dan anak sehingga pembentukan P2TP2A di masing-masing wilayah sangat dibutuhkan. Selain itu, P2TP2A juga dipercaya sebagai salah satu fungsi kontrol sosial terhadap masyarakat dalam pencegahan terjadinya tindak pidana. Ketiadaan P2TP2A di Wilayah Majalengka di back up oleh BPMDPKB sehingga konsentrasi bantuan masalah anak yang seharusnya fokus dikerjakan oleh P2TP2A kurang maksimal karena BPMDPKB juga menangani seluruh masalah yang terjadi di lapisan masyarakat dan desa sehingga kurang fokus dalam memberi perhatian kepada masalah anak terutama anak berhadapan dengan hukum. Kebutuhan P2TP2A dirasakan sangat perlu karena membantu aparat penegakkan hukum dalam 
pencegahan dan pembinaan seperti: konsultasi, bantuan kepada korban, sosialisasi, trauma centre serta pembinaan kepada anak pelaku tindak pidana.

c. Tidak adanya LPKA, LPKS dan LPAS di Wilayah Hukum Polres Majalengka

Dalam hal anak belum berumur 14 (empat belas) tahun dan tidak melakukan tindak pidana dengan ancaman pidana penjara 7 (tujuh) tahun atau lebih, maka anak pelaku akan di tempatkan di LPKA (Lembaga Pembinaan Khusus Anak) atau LPAS (Lembaga Pembinaan Anak Sementara) atau LPKS (Lembaga Penyelenggaraan Kesejahteraan Sosial) di Wilayah Hukum Polres Majalengka sebagaimana dimaksud dalam ketentuan Pasal 33 UndangUndang Nomor 11 Tahun 2012 Tentang Sistem Peradilan Pidana Anak. Namun karena ketidakberadaan LPKA, LPAS maupun LPKS di Wilayah Hukum Polres Majalengka, maka anak pelaku tidak dilakukan penahanan tetapi dikenakan wajib lapor kepada penyidik setiap 2 (dua) kali dalam seminggu dengan jaminan pengawasan oleh ketua lingkungan setempat dan keluarga. Tentu saja hal ini dirasakan cukup beresiko oleh penyidik khususnya penyidik di Kepolisian Resor Majalengka karena dikhawatirkan anak pelaku akan melarikan diri atau tidak terjamin keselamatannya jika berada di tengah masyarakat. Sehingga pemantauan melalui wajib lapor di rasa kurang efisien karena tidak menjamin pasti keberadaan dan keselamatan anak pelaku selama kasus masih dalam proses penyidikan.

d. Belum terwujudnya kewajiban Pemerintah dalam mengeluarkan 6 (enam) Peraturan Pemerintah dan 2 (dua) Peraturan Presiden sebagaimana yang telah diamanatkan ke dalam Pasal 107 UU Nomor 11 Tahun 2012 tentang Sistem Peradilan Pidana Anak.

Ada beberapa implikasi yang dapat terjadi apabila Peraturan Pelaksana tidak juga dirampugkan dengan kualitas yang baik yang diantaranya adalah, Pertama, terjadi kekosongan hukum dalam pelaksanaan suatu aturan. 
UUSPPA masih sangat umum menjelaskan terkait beberapa ketentuan, untuk itu diperlukan peraturan pelaksana untuk secara komperhensif menjelaskan suatu aturan dalam Undang-Undang. Misalnya dalam hal program pendidikan, pembinaan, dan pembimbingan dalam hal Anak belum berumur 12 (dua belas) tahun melakukan atau diduga melakukan tindak pidana, tanpa peraturan pelaksana maka dapat dipastikan akan ada kekosongan pengaturan mengenai program pendidikan, pembinaan, dan pembimbingan bagi anak belum berumur 12 tahun. Sementara itu saat ini tidak ada satu pun aturan di Indonesia baik Undang-Undang maupun turunannya yang mengatur mengenai hal ini. Kedua, tidak aturan yang mengikat aparat penegak hukum secara keseluruhan. Dampak ini bisa dilihat dalam pengaturan Diversi, namun aturan teknis tersebut hanya berlaku di lingkungan peradilan umum. Situasi ini akan berujung pada permasalahan ketika terjadi standar berbeda terhadap Diversi yang ada di Kepolisian, Kejaksaan, Pengadilan. Ketiga, UUSPPA semakin lama bisa diterapkan. Tantang terbesar dalam mengubah suatu sistem tentu saja berhubungan dengan mengubah kebiasaan dari pihak-pihak yang berada dalam sistem tersebut. SPPA merupakan sistem baru yang diperkenalkan dalam sistem peradilan pidana di Indonesia. Kekosongan peraturan pelaksana untuk mengefektifkan UUSPPA tentu saja berdampak pada tertundanya pemberlakuan UUSPPA dengan efektif pula. Hasilnya, tentu saja terancamnya hak dan kepentingan anak yang diatur dalam UUSPPA

e. Pelaksanaan Peraturan Mahkamah Agung Nomor 4 Tahun 2014 Tentang Pelaksanaan Diversi Dalam Sistem Peradilan Pidana Anak pada perkara anak dengan ancaman di atas 7 (tujuh) tahun hanya bisa dilaksanakan di Pengadilan.

Dari ketentuan Pasal 8 Ayat (1) Undang-Undang Nomor 12 tahun 2011 tentang Pembentukan Peraturan Perundangan-Undangan, 
Peraturan Mahkamah Agung diakui keberadaannya sebagai jenis peraturan perundang-undangan dan mempunyai kekuatan hukum yang mengikat sepanjang diperlukan oleh Undang-Undang yang lebih tinggi atau dibentuk berdasarkan kewenangan. Frasa kekuatan hukum disini adalah sesuai dengan hierarki peraturan perundangundangan, yaitu perjenjangan setiap jenis dan peraturan perundang-undangan yang didasarkan asas bahwa peraturan perundang-undangan yang lebih rendah tidak boleh bertentangan dengan peraturan perundangundangan yang lebih tinggi (Yuliandri, 2010:67-68).

\section{SIMPULAN}

1. Implementasi diversi terhadap anak sebagai pelaku tindak pidana dalam sistem peradilan anak di Wilayah Hukum Kabupaten Majalengka oleh Unit PPA Polres Majalengka berdasarkan UU Nomor 11 Tahun 2012 tentang Sistem Peradilan Pidana Anak dalam prakteknya menemukan mayoritas jenis kasus anak berhadapan dengan hukum sejak tahun 2011 sampai dengan tahun 2016 adalah persetubuhan dan pencabulan yang memiliki ancaman pidana penjara 5 (lima) sampai 15 (lima belas) tahun. Sehingga implementasi diversi yang dilakukan Polres Majalengka belum banyak dilaksanakan karena jenis kasus yang marak di Majalengka tidak memenuhi syarat untuk dilakukannya proses diversi sebagaimana dicantumkan dalam Pasal 7 UU Nomor 11 Tahun 2012 tentang Sistem Peradilan Pidana Anak.

2. Hambatan Unit PPA Polres Majalengka adalah Kurangnya Penyidik Anak di dalam Struktur Organisasi Unit PPA Polres Majalengka, Tidak Adanya Lembaga P2TP2A, Tidak Adanya LPKA, LPAS dan LPKS di Wilayah Hukum Kabupaten Majalengka, Belum Terwujudnya Kewajiban Pemerintah dalam mengeluarkan $6 \quad$ (enam) Peraturan Pemerintah dan 2 
(dua) Peraturan Presiden sebagaimana yang telah diamanatkan ke dalam Pasal 107 UU Nomor 11 Tahun 2012 tentang Sistem Peradilan Pidana Anak dan Pelaksanaan Peraturan Mahkamah Agung Nomor 4 tahun 2014 tentang Pedoman Pelaksanaan Diversi Dalam Sistem Peradilan Pidana (terutama dalam tindak pidana dengan ancaman di atas 7 tahun) hanya bisa dilaksanakan di Pengadilan.

\section{SARAN}

1. Melakukan kerjasama dan membuat SOP (Standard Operational Procedure) atau MoU (Memorandum of Understanding) dengan para masyarakat, tokoh agama, lingkungan sekolah, pemerhati anak, kepolisian dan organisasi lain yang bergerak di bidang anak untuk menciptakan lingkungan yang santri dan menolak adanya free sex sebelum menikah serta menciptakan masyarakat sadar hukum sehingga tidak akan ada lagi pembiaran terhadap tindak pidana persetubuhan dan atau pencabulan yang dilakukan oleh anak-anak di bawah umur.

2. Memperbanyak kesempatan dengan mengadakan pelatihan penyidk anak kepada anggota yang belum memiliki sertifikasi penyidik, mempertimbangkan pendirian P2TP2A, LPKA, LPKS, LPAS, serta serta kepada Pemerintah untuk merespon pembentukan Peraturan Pemerintah dan Peraturan Presiden yang sebagaimana telah diamanatkan dalam UU Nomor 11 Tahun 2012 tentang Sistem Peradilan Pidana Anak.

3. Melakukan persamaan persepsi antara Undang-Undang Nomor 11 Tahun 2012 tentang Sistem Peradilan Pidana Anak dengan Peraturan Mahkamah Agung Nomor 4 tahun 2014 tentang Pedoman Pelaksanaan Diversi Dalam Sistem Peradilan Pidana terkait salah satu syarat diversi adalah tindak pidana dengan ancaman di bawah tujuh tahun. 


\section{DAFTAR PUSTAKA}

Ediwarman, Peradilan Anak di Persimpangan Jalan dalam Prespektif Victimologi (Belajar dari Kasus Raju), Jurnal Mahkamah Vol. 18 No. 1, Fakultas Hukum Universitas Lancakuning, Pekan Baru, 2006.

Marlina, Pengantar Konsep Diversi dan Restorative Justice dalam Hukum Pidana, USU Press, Medan, 2010.

Romli Atmasasmita, Peradilan Anak di Indonesia, Mandar Maju, Bandung, 2007.

Setya Wahyudi, Implementasi Ide Diversi Dalam Pembaruan Sistem Peradilan Pidana Anak di Indonesia, Genta Publishing, Yogyakarta, 2011.

Suharsimi Arikunto, Dasar-dasar Evaluasi Pendidikan, Bumi Aksara, Jakarta, 2006.

Wagiati Soetedjo dan Melani, Hukum Pidana Anak, Cetakan ke-4 Ed. Revisi, Refika Aditama, Bandung, 2006.

Yuliandri, Asas-Asas Pembentukan

Peraturan Perundang-
Undangan yang Baik;
Gagasan

Undang-Undang

Berkelanjutan, PT Raja Grafindo Persada, Jakarta, 2010 . 